\title{
Acute whiplash associated disorders (WAD)
}

This article was published in the following Dove Press journal:

Open Access Emergency Medicine

26 April 20II

Number of times this article has been viewed

\section{Khushnum Pastakia \\ Saravana Kumar}

International Centre for Allied Health Evidence, University of South Australia, Adelaide, SA, Australia

Date of preparation: 27 th January 20II

Conflict of interest: None declared
Correspondence: Khushnum Pastakia International Centre for Allied Health Evidence, University of South Australia, GPO Box 247I, City East Campus, Adelaide, SA 500I, Australia

Tel +6I 883022085

Fax +6I 883022766

Email khushnum.pastakia@unisa.edu.au
Background: Whiplash-associated disorder (WAD) is the term given for the collection of symptoms affecting the neck that are triggered by an accident with an acceleration-deceleration mechanism such as a motor vehicle accident. The incidence of whiplash injury varies greatly between different parts of the world with significant monetary burden on the individual as well as the wider community.

Objective: Which treatments are best for reducing pain and disability experience in acute WADs?

Level of evidence: Clinical practice guidelines, systematic reviews, meta-analysis, randomized controlled trials.

Search sources: PubMed, Cochrane Library, Medline, EMBASE, AUST health, AMED.

Outcomes: From the patient perspective the main outcomes considered are pain and disability.

Consumer summary: Whiplash-associated disorders include a range of symptoms related to the neck and head. They commonly occur after motor vehicle accidents or diving mishaps. There is good evidence to suggest that active exercise, acting as usual and combination therapy are the most effective treatment choices in an acute presentation.

Keywords: whiplash, neckpain, pain levels, multimodel therapy

\section{Acute whiplash associated disorders (WAD)}

Definition: Whiplash can be defined as "an acceleration-deceleration mechanism of energy transfer to the neck. It may result from rear-end or side-impact motor vehicle collisions, but can also occur during diving or other mishaps. The impact may result in bony or soft-tissue injuries (whiplash-injury), which in turn may lead to a variety of clinical manifestations called Whiplash-Associated Disorders". ${ }^{1}$

Whiplash-associated disorder (WAD) is the term given for the collection of symptoms affecting the neck that are triggered by an accident with an acceleration-deceleration mechanism such as a motor vehicle accident. ${ }^{2}$ The Quebec Task Force classifies patients with whiplash, based on the severity of signs and symptoms, as follows: ${ }^{3}$

Grade 0: No complaints about the neck. No physical sign(s).

Grade I: Neck complaint of pain, stiffness or tenderness only. No physical $\operatorname{sign}(\mathrm{s})$.

Grade II: Neck complaint AND musculoskeletal sign(s). Musculoskeletal signs include decreased range of motion and point tenderness.

Grade III: Neck complaint AND neurological sign(s). Neurological signs include decreased range of motion and point tenderness. 
Grade IV: Neck complaint AND fracture or dislocation.

The worldwide annual incidence of symptomatic whiplash injuries varies between 16 and 200 per 100,000. ${ }^{4}$ The incidence of whiplash injury varies greatly between different parts of the world, with rates as high as 70 per 100,000 inhabitants in Quebec, Canada, 106 per 100,000 in Australia, and 188 to 325 per 100,000 inhabitants in the Netherlands. ${ }^{5}$

According to the World Health Organisation, traffic injuries constitute approximately $1 \%$ of the combined gross national products of the nations of the western world. ${ }^{5}$ One review states that $20 \%-40 \%$ of whiplash patients tend to develop chronic symptoms. ${ }^{6}$ It is reported that WAD account for $42 \%$ of compulsory third party claims in New South Wales, Australia, and the cost associated with rehabilitating whiplash is the highest of any musculoskeletal injury in the scheme. ${ }^{7}$ This results in a significant monetary burden on the individual as well as the wider community.

\section{The evidence}

\section{Which treatments are best for reducing pain and disability experience in acute WADs?}

\section{Active exercise}

Clinical practice guidelines 3

Systematic reviews 3

Meta-analysis 1

Randomized controlled trials 2

The guidelines ${ }^{3,8,9}$ recommend that implementing range of motion exercises immediately results in reduced pain levels and improved function.

The systematic reviews ${ }^{10-12}$ found that exercise (range of motion and neck and scapular strengthening exercises) is beneficial in relieving neck pain in acute whiplash injuries. One systematic review ${ }^{12}$ cautions that exercise may produce transitory increase in pain levels but is beneficial in the long run for reducing pain.

The meta-analysis ${ }^{13}$ concluded that specific exercises such as neck stabilization exercise showed significant short-term effects on pain levels in whiplash disorders.

Randomized controlled trials (RCTs) generally found that active exercises were more effective in reducing pain and improving function especially when implemented early (within 96 hours) after injury (Table 1).

Conclusions: Following a whiplash injury, early implementation of active exercise has a positive effect on pain and disability. It is best to seek advice from your doctor or health provider before performing exercises.

\section{Act as usual}

Clinical practice guidelines 3

Systematic reviews 3

RCTs 1
The guidelines ${ }^{3,8,9}$ concluded that patients who act as usual post-whiplash injury have significantly better outcomes with respect to pain and function.

The systematic reviews ${ }^{15-17}$ recommend that patients suffering from acute WAD be prescribed advice to "act as usual" as it encourages function early on after the injury and thus results in reduced disability and pain.

The $\mathrm{RCT}^{18}$ concluded that "act as usual" advice by itself is a sufficient intervention to reduce pain when the initial pain intensity is fairly low. In the case of higher pain intensities, it works best when used in conjunction with other active forms of therapy such as exercise.

Conclusions: "Act as usual" within tolerable levels for a WAD is effective in reducing pain and improving function, especially in the early stages after the injury.

\section{Multimodal therapy}

Clinical practice guidelines 2

Systematic reviews 3

The guidelines ${ }^{3,9}$ conclude that multimodal therapy can be used for a WAD that has not settled within 4 to 6 weeks providing there is evidence of continuing improvement with the treatment.

The systematic reviews ${ }^{13,17,19}$ state that there is strong evidence for multimodal therapy that includes mobilization, relaxation, and an exercise focus. The therapy may also include medication, heat/cold therapy, and education.

One of the reviews ${ }^{17}$ found strong evidence supporting the use of multimodal therapy in the period between 2 and 12 weeks following whiplash injury.

Conclusions: Multimodal therapy may be more effective than individual treatments provided in isolation. It should consist of at least mobilization and/or mobilization and some form of exercise. 
Table I RCTs comparing active intervention versus other conservative interventions

\begin{tabular}{|c|c|c|c|c|}
\hline Author & Number randomized & Interventions & Outcome measures & Results \\
\hline \multirow[t]{2}{*}{ Rosenfeld $2006^{5}$} & 100 & $\begin{array}{l}\text { Group I: Active involvement and } \\
\text { intervention using early } \\
\text { mobilization }\end{array}$ & Pain & $\begin{array}{l}\text { Active intervention } \\
\text { group experienced } \\
\text { reduced pain and costs }\end{array}$ \\
\hline & & $\begin{array}{l}\text { Group 2: A standard intervention } \\
\text { of rest, recommended short-term } \\
\text { immobilization in a cervical collar } \\
\text { and a cautious, gradual self-exercise } \\
\text { program according to a leaflet }\end{array}$ & Cost of treatment & \\
\hline \multirow[t]{2}{*}{ Schnabel $2004^{14}$} & 200 & Group I: Used a collar & Pain & $\begin{array}{l}\text { Early exercise therapy is } \\
\text { superior to the collar } \\
\text { therapy for reducing } \\
\text { pain intensity and } \\
\text { disability }\end{array}$ \\
\hline & & Group 2: Active exercises & Disability & \\
\hline
\end{tabular}

\section{The practice}

\section{Potential pitfalls}

As whiplash can be a traumatic event, care should be taken, especially in the initial stages, to closely monitor the patient's progress. Be sure to work within the patient's pain threshold (as it may vary from one individual to another) and progress treatments slowly to avoid sudden flare-ups.

\section{Management}

Acute WAD can be managed by a number of health professionals, namely, general practitioners, physiotherapists, and chiropractors. Indications for specialist referral are given below.

\section{Assessment}

- A detailed subjective examination, including current and past history, mechanism of injury, behavior of symptoms, and detailed description of symptoms should be undertaken. As part of routine screening, a detailed overview of general health, social support, and medical history should be undertaken.

- Objective assessment of the neck includes:

- Range of motion, active and passive (physiological and accessory)

- Palpation of the cervical and thoracic region

- Cervicothoracic musculature (length and strength)

- Neural dynamics

- Neurological

- Vertebrobasilar insufficiency (VBI)

\section{Treatment}

- Provide patient with general mobility exercises for the cervical and thoracic spine.

- Stabilization exercises should be provided, targeting deep neck flexors and scapula stabilizers.

- Especially in the early stages, it is important to advise patients to act as usual (eg, continue with their activities of daily living) within tolerable levels to promote early return to function.

- Avoidance of movement due to fear of pain, especially in the early stages of whiplash, could result in prolonging the symptoms and delaying recovery. Therefore reassure the patient that continuing to maintain movement is harmless and will aid in long-term improvement.

- Educate the patient about the mechanism of injury, structures affected and provide a realistic overview of treatment options and prognosis.

- As part of the ongoing management of a patient with whiplash, multimodal therapy could also be considered. Multimodal therapy can be in the form of manual therapies (such as joint mobilization), relaxation techniques, ongoing education, and exercises. These treatments can be provided as a package of care.

\section{Indications for specialist referral}

- Grade IV WAD

- Worsening signs and symptoms despite treatment

- Signs and symptoms of VBI

- Signs and symptoms of neurological involvement 


\section{Further reading}

Publications from The Bone and Joint Decade 2000-2010 Task Force on Neck Pain and Its Associated Disorders. Available at http://journals.lww. com/spinejournal/toc/2008/02151. Accessed March 19, 2011.

Evidence summaries on conservative treatment of WAD. Available at: $\mathrm{http}: / /$ www2.som.uq.edu.au/som/Research/Whiplash/Pages/default.aspx. Accessed March 19, 2011.

\section{References}

1. Spitzer WO, Skovron ML, Salmi LR, et al. Scientific monograph of the Quebec Task Force on Whiplash Associated Disorders: redefining 'whiplash' and it's management. Spine. 1995;20:8S-58S

2. Suijlekom HV, Mekhail N, Patel N, Zundert JV, Kleef MV, Patijn J. Whiplash-associated disorder. Pain Practice. 2010;10:131-136.

3. TRACsa: Trauma and Injury Recovery. Clinical guidelines for best practice management of acute and chronic whiplash-associated disorders. Adelaide, Australia: South Australian Centre for Trauma and Injury Recovery (TRACsa); 2008.

4. Pato U, Stefano GD, Fravi N, et al. Comparison of randomized treatments for late whiplash. Neurology. 2010;74:1223-1230.

5. Rosenfeld M, Seferiadis A, Gunnarsson R. Active involvement and intervention in patients exposed to whiplash trauma in automobile crashes reduces costs a randomized, controlled clinical trial and health economic evaluation. Spine. 31;16:1799-1804.

6. Verhagen AP, Scholten-Peeters GGGM, van Wijngaarden S, de Bie R, Bierma-Zeinstra SMA. Conservative treatments for whiplash. Cochrane Database Syst Rev. 2007;(2):CD003338.

7. Rebbeck T, Maher C, Refshauge K. Evaluating two implementation strategies for whiplash guidelines In physiotherapy: a cluster-randomised trial. Aust J Physiother. 2006;52:165-174.

8. Motor Accidents Authority. Guidelines for management of whiplash associated disorders. Sydney, Australia: Motor Accidents Authority; 2001.
9. Motor Accidents Authority. Your guide to whiplash recovery in the first 12 weeks after the accident. Sydney, Australia: Motor Accidents Authority; 2007.

10. Kay TM, Gross A, Goldsmith C, Santaguida PL, Hoving J, Bronfort G. Cervical Overview Group. Exercises for mechanical neck disorders. Cochrane Database Syst Rev. 2005;(3):CD004250.

11. Peeters GGM, Verhagen AP, Bie RA, Oostendorp RAB. The efficacy of conservative treatment in patients with whiplash injury: a systematic review of clinical trials. Spine. 26;4:64-73.

12. Guzman J, Haldeman S, Carroll LJ, et al. Task force on neck pain and its associated disorders. J Manipulative and Physiol Ther. 2009;32:227-243.

13. Leaver AM, Refshauge KM, Maher CG, McAuley JH. Conservative interventions provide short-term relief for non-specific neck pain: a systematic review. J Physiother. 2010;56:73-85.

14. Schnabel M, Ferrari R, Vassiliou T, Kaluza G. Randomized controlled outcome study of active mobilization compared with collar therapy for whiplash injury. Emerg Med J. 2004;21:306-310.

15. Binder A. The diagnosis and treatment of nonspecific neck pain and whiplash. Eura Medicophysics. 2007;43:79-89.

16. Seferiadis A, Rosenfeld M, Gunnarsson R. A review of treatment interventions in whiplash-associated disorders. Eur Spine J. 2004;13:387-397.

17. Mercer C, Jackson A, Moore A. Developing clinical guidelines for the physiotherapy management of whiplash associated disorder (WAD). Int J Osteopathic Med. 2007;10;2-3,50-54.

18. Dehner C, Elbel M, Strobel P, et al. Grade II whiplash injuries to the neck: what is the benefit for patients treated by different physical therapy modalities? Patient Saf Surg. 2009;3:2.

19. Miller J, Gross A, D'Sylva J, et al. Manual therapy and exercise for neck pain: a systematic review. Man Ther. 2010;15:334-354.
Open Access Emergency Medicine

\section{Publish your work in this journal}

Open Access Emergency Medicine is an international, peer-reviewed, open access journal publishing original research, reports, editorials, reviews and commentaries on all aspects of emergency medicine. The manuscript management system is completely online and includes a very quick and fair peer-review system, which is all easy to use.

\section{Dovepress}

Visit http://www.dovepress.com/testimonials.php to read real quotes from published authors. 